\title{
Farmer perceptions of plant-soil interactions can affect adoption of sustainable management practices in cocoa agroforests: a case study from Southeast Sulawesi
}

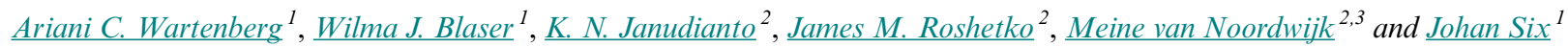

\begin{abstract}
Despite extensive research focused on increasing the sustainability and productivity of agricultural systems in the tropics, adoption rates of improved management solutions often remain low among smallholder farmers. To address this, we evaluated how local knowledge and perceptions influenced decision-making processes among smallholder cocoa farmers. We conducted individual semistructured interviews with 72 cocoa farmers in Southeast Sulawesi and documented local knowledge about soil fertility indicators, nutrient cycling processes, and the interactions among shade trees, cocoa trees, and soils in cocoa agroforests. We further collected data regarding farmers' fertilizer preferences, additional income sources, and perceived barriers to improved cocoa production. We found that farmers' understanding of biophysical interactions in Southeast Sulawesi was comprehensive, mostly accurately aligned with scientific literature, and sometimes provided additional complementary knowledge. Cocoa farmers in Southeast Sulawesi approached decision making in a holistic way, integrating personal observations, information from external sources, and socioeconomic limitations and priorities. This finding highlights the value of flexible conservation farming approaches that allow farmers to minimize trade-offs and prioritize their households' needs. Finally, we identify a "dual" knowledge gap on the part of farmers and scientists regarding the direct benefits of shade tree inclusion for improved yields and income security. Addressing this through further research and targeted knowledge dissemination could contribute to an increase in the long-term adoption rates of more sustainable cocoa cultivation practices.
\end{abstract}

Key Words: adoption rates; local knowledge; shade tree inclusion; smallholder farmers; soil fertility; sustainable management practices; Theobroma cacao

\section{INTRODUCTION}

There are currently approximately 2.5 billion smallholders worldwide (International Fund for Agricultural Development (IFAD) 2013) who represent the backbone of global agriculture (Tscharntke et al. 2012) yet are particularly vulnerable to food insecurity. Smallholder farmers generally rely on annual yields to sustain their livelihoods and frequently do not have access to economic or social safety nets (Barrett and Bevis 2015). Researchers and practitioners have stressed the links among rural poverty, food insecurity, and soil degradation for several decades (Sanchez et al. 1997, Tilman et al. 2002, Barrett and Bevis 2015). Nevertheless, soil degradation and the related decline in food production remain central issues in vulnerable agrarian regions and are exacerbated by poor management practices, population growth (Vanlauwe et al. 2015), and climate change (Mbow et al. 2014). The development of more sustainable crop production practices targeted at empowering smallholders through long-term reduction of poverty and soil degradation is therefore crucial. Tropical agroforestry systems are frequently cited as a potential solution to these issues, as they are believed to offer the potential to integrate incomes and enhanced ecosystem resilience and functioning (e.g., Franzen and Mulder 2007, Tscharntke et al. 2012, Mbow et al. 2014). This is particularly relevant for cash crops such as cocoa or coffee, which are shade-tolerant understory tree species traditionally grown in agroforests (Schroth et al. 2004).
Farmer-driven initiatives aiming to improve the sustainability of cocoa cultivation, for instance through diversification, are an important vehicle to improve rural livelihoods. However, to promote the adoption of locally appropriate management approaches in these systems, it is first necessary to understand the drivers of smallholders' decision-making processes (Barrett and Bevis 2015). A number of studies have examined rural incentive structures (e.g., Shiferaw et al. 2009) and the socioeconomic and environmental factors that drive land-use change and farm management in rural tropical areas (Clough et al. 2016). Such research has shown that smallholders often base their management decisions on factors that can include but are not limited to their understanding of ecological processes. Smallholders often integrate their observations of biophysical processes with external sources of information (from other farmers, extension agents, etc.) to guide farm-related management decisions (Pauli et al. 2012, Villamor et al. 2014, Mulyoutami et al. 2015). There is also a growing body of literature exploring the role of local knowledge for sustainable farm development (e.g., Isaac et al. 2009, Raymond et al. 2010, Meijer et al. 2015).

The differences between local and scientific knowledge on soil fertility have been discussed extensively, along with the different criteria by which farmers from around the world classify soils (e.g., Talawar and Rhoades 1998, Joshi et al. 2004, Dawoe et al. 2012). Although farmer classifications of soil physical

\footnotetext{
${ }^{1}$ Department of Environmental Systems Science, Swiss Federal Institute of Technology, ETH Zürich, Zurich, Switzerland, ${ }^{2}$ World Agroforestry Centre, ICRAF Southeast Asia Regional Office, Bogor, Indonesia, ${ }^{3}$ Plant Production Systems, Wageningen University and Research, Wageningen, the Netherlands
} 
properties have been shown to match scientific assessments (Saito et al. 2006), farmer knowledge frequently diverges from scientific consensus when it comes to relating ecosystem services (e.g., enhanced soil fertility) to changes in crop productivity (Barrios and Trejo 2003, Gray and Morant 2003). Such knowledge gaps might be caused by farmers' limited access to information, but can also highlight aspects of ecosystem functions not yet fully understood by formal science.

In the context of cocoa cultivation, the benefits of mixed agroforestry systems have been widely studied from ecological and economic perspectives. To date, scientists have come up with a plethora of findings and recommendations aimed at improving the sustainability of cocoa cultivation (Franzen and Mulder 2007, Tscharntke et al. 2011, Clough et al. 2016). Despite this, longterm adoption rates remain low in most cocoa-producing countries (Ruf 2011, Martini et al. 2017). In Indonesia, cocoa farmers are moving toward intensification of their farms, and simple cocoa agroforests interplanted with single species, such as coconut, gliricidia, or patchouli, are prevalent (Feintrenie et al. 2010, Rahmanulloh et al. 2012). Limited adoption of farm diversification practices might be related to our limited understanding of the drivers of smallholders' decision making. Indeed, policy and agricultural extension solutions might not sufficiently take into account local knowledge and farmers' perceptions about yield-related ecosystem services (e.g., improved nutrient cycling, pest and disease control, etc.) commonly associated with agroforests (e.g., Ruf 2011).

Systematic integration of local and scientific knowledge could improve our understanding of the mechanisms through which soil fertility changes can impact crop productivity (Gray and Morant 2003) and promote the application of participatory approaches (i.e., multistakeholder workshops or knowledge exchange between farmers and researchers or policy makers), which have been shown to increase adoption rates of sustainable farming practices (Smith-Dumont et al. 2017). Several studies have separately assessed local knowledge about soil fertility and soil management (Barrios and Trejo 2003, Dawoe et al. 2012) and the influence of farmer perceptions and other factors on adoption rates of agricultural management practices in smallholder farms (Pattanayak et al. 2003, Meijer et al. 2015). To our knowledge, few studies have bridged both areas of research by examining the extent of local knowledge about ecological processes, and relating this to external farm-related pressures and management decisions (Wyckhuys and O'Neil 2007, Isaac et al. 2009, Smith-Dumont et al. 2017).

In this case study, we conducted interviews in 72 cocoa farming households in Southeast Sulawesi to understand farmers' perceptions of biophysical processes related to tree-soil-cocoa interactions. Our objectives were to (i) identify and document farmers' knowledge and perceptions about visible soil fertility attributes, shade tree and soil interactions, and shade tree effects on cocoa tree development and productivity; (ii) compare farmers' knowledge about biophysical processes and the interactions between different ecosystem components with scientific literature; (iii) determine to what extent the optimization of ecological processes is taken into account by farmers in comparison with external pressures (e.g., input availability, market-driven price fluctuations). Our aim was to provide information about the relationship between local knowledge and smallholder decision-making processes in cocoa cultivation systems and to contribute to the development of more sustainable and locally appropriate management recommendations.

\section{METHODS}

\section{Study area}

This study was conducted in the Konawe and Kolaka provinces in Southeast Sulawesi $\left(3.58^{\circ} \mathrm{S}, 122.30^{\circ} \mathrm{E}\right.$; Fig. 1). The agricultural landscape of the region is dominated by paddy rice, maize, and vegetable production. Surrounding mountain ranges are still widely forested, although at forest frontiers, deforestation and land-use changes are expanding rapidly. Soils in Southeast Sulawesi are predominantly orthic acrisols in mountainous areas, and dystric fluvisols in the floodplains (Food and Agriculture Organization (FAO) 1979). Mean daily temperatures range between $25-28^{\circ} \mathrm{C}$, and the rainy season lasts from January to June, with an average annual precipitation of about $2080 \mathrm{~mm}$ (ClimateData.org 2016). We selected six cocoa-producing communities in the study area: Wonuahoa, Asinua Jaya, and Lawonua in Kolaka province; and Tasahea, Andowengga, and Simbune in Konawe province. All communities were included in the scope of the "Agroforestry and Forestry in Sulawesi" (AgFor) project of the International Centre for Research in Agroforestry (ICRAF) World Agroforestry Centre, which aims to improve rural livelihoods and enhance sustainable natural resource management by focusing on agroforestry systems.

Fig. 1. Map of the study area of Southeast Sulawesi, indicating the six communities selected for this study: Wonuahoa, Asinua Jaya, and Lawonua in Kolaka province; and Tasahea, Andowengga, and Simbune in Konawe province.

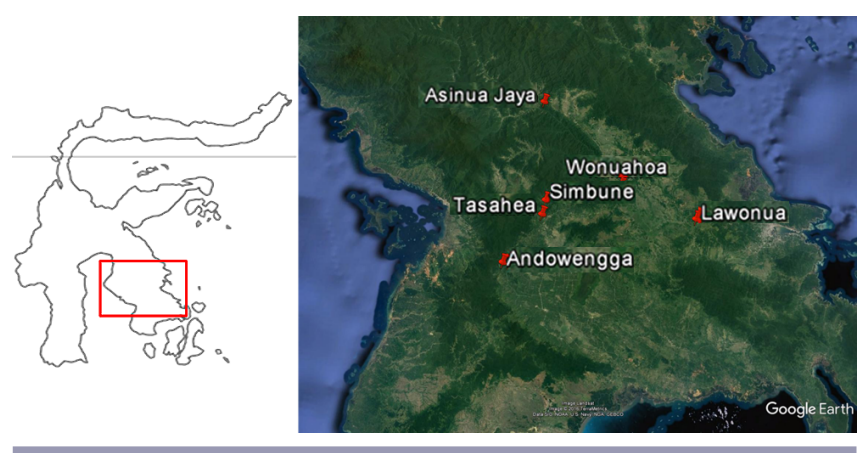

Communities in Southeast Sulawesi have been classified into three different typologies: local, local/migrant, and transmigrant (Janudianto et al. 2012). Wonuahoa and Simbune are local villages, and most households belong to the Tolaki ethnic group, which is indigenous to Southeast Sulawesi. Lawonua, originally established in the 1930s, is a local/migrant village and has a mix of local Tolaki families and Bugis migrants from south Sulawesi. In Tasahea, Asinua Jaya, and Andowengga, most families are transmigrants from south Sulawesi or other Indonesian islands (Bali or Java).

Cocoa, which was introduced in the region in the 1980s, is the principal livelihood source for most households, followed by paddy rice and pepper (Janudianto et al. 2012). Cocoa agroforests are, for the most part, established directly on previously forested 
Table 1. Description of study respondents in Southeast Sulawesi grouped by community ( $n=12$ per community). Farmer group membership refers to respondents' membership in a local farmer group or cooperative.

\begin{tabular}{lcccccc}
\hline \hline Community & \multicolumn{2}{c}{ Gender } & Years of Education & Age & Farmer Group Membership & Years farming cacao \\
\cline { 2 - 3 } & $\mathrm{M}$ & $\mathrm{F}$ & & & & \\
\hline Tasahea & $67 \%$ & $33 \%$ & $9 \pm 5$ & $44 \pm 7$ & $100 \%$ & $19 \pm 7$ \\
Andowengga & $83 \%$ & $17 \%$ & $8 \pm 4$ & $47 \pm 12$ & $67 \%$ & $19 \pm 6$ \\
Simbune & $75 \%$ & $25 \%$ & $11 \pm 3$ & $48 \pm 10$ & $75 \%$ & $19 \pm 11$ \\
Wonuahoa & $67 \%$ & $33 \%$ & $8 \pm 4$ & $43 \pm 12$ & $75 \%$ & $9 \pm 7$ \\
Lawonua & $67 \%$ & $33 \%$ & $7 \pm 4$ & $41 \pm 13$ & $58 \%$ & $14 \pm 6$ \\
Asinua Jaya & $50 \%$ & $50 \%$ & $11 \pm 3$ & $40 \pm 12$ & $75 \%$ & $16 \pm 8$ \\
Total & $68 \%$ & $32 \%$ & $9 \pm 4$ & $44 \pm 11$ & $75 \%$ \\
\hline
\end{tabular}

areas that are cleared gradually by manual cutting of trees and undergrowth. The agroforests in the region consist of mixed stands of cocoa intercropped with various shade trees.

\section{Survey design and description of variables}

In June and July 2015, we conducted semistructured farmer interviews with 72 smallholder cocoa farmers. Twelve farmers were selected from each of the six communities listed above using random stratification within strata defined by occupation (cocoa farmers) and gender. Although it was difficult to identify female cocoa farmers willing to be interviewed individually, we ensured that at least one-third of respondents in each village were women. For each respondent, we recorded age, gender, farmer group membership status, place of birth, and education level (Table 1). All interviews were conducted individually in Bahasa Indonesia, with the assistance of a local translator, and lasted approximately 45-60 min each.

Our questionnaire was composed of closed and open-ended questions. For open-ended questions, responses were classified into categories after the interviews were completed to facilitate and standardize data analysis. Questions focused on six topics: farmer and household history (see Table 1), soil fertility indicators, shade tree impacts on soil fertility, shade tree impacts on cocoa, access to extension services, and limiting factors for cocoa productivity. To understand farmer perceptions of significant soil fertility indicators, we selected seven commonly used soil fertility indicators: stone content, soil color, soil litter layer, soil structure, macrofauna content, soil texture, and waterholding capacity/porosity (e.g., Doran and Parkin 1994, Pauli et al. 2012). For each indicator, study participants were asked to indicate optimal soil conditions, using visual vignettes for each indicator. We then asked participants to rank indicators according to their perceived importance for cocoa production.

We asked all survey participants open-ended questions about (a) attributes of shade trees that can modify soil indicators, and (b) participants' perceptions about shade tree impacts on soil fertility and cocoa development. Responses were coded and classified into the following categories: shading and protection, cocoa tree health, nutrients and resources, root systems, and pest and disease occurrence. Based on observations in the field and on discussions with farmers, farming extension agents, and AgFor project staff, we identified six shade tree species commonly intercropped with Theobroma cacao (cocoa) in Southeast Sulawesi: Gliricidia sepium (gliricidia), Nephelium lappaceum (rambutan), Durio zibethinus (durian), Mangifera indica (mango), Gmelina arborea (white teak), and Lansium domesticum (langsat). Gliricidia is a nitrogen- fixing tree originally native to Central America (Roshetko 2001). Durian, rambutan, and langsat are fruit trees native to Southeast Asia, including Sulawesi. Both white teak, principally used for timber, and mango are originally native to South Asia, although mango trees have been naturalized throughout Indonesia for centuries (Orwa et al. 2009). Respondents were asked to evaluate the effects of each species on soil fertility and cocoa trees. We then coded answers and classified them into three soil characteristics (soil structure, soil nutrients, and soil moisture) and four cocoa tree characteristics (pest and disease occurrence, shade and protection, cocoa pod yields, and cocoa tree growth). We also recorded common secondary uses for all shade tree species and asked farmers how they had acquired knowledge about shade tree selection, planting practices, ongoing management, and fertilization application. Respondents were further asked about their membership in farmer associations, their preferences regarding organic and chemical fertilizer application, and the principal obstacles that they viewed as limiting to cocoa productivity.

\section{Data analysis}

All data were analyzed for the entire population of respondents. We first used frequency distribution analysis to quantify responses for the following groups of variables: respondent characteristics, soil fertility indicators, shade tree effects, knowledge extension, fertilizer use, and obstacles to cocoa production. Because our data did not have the normal distribution assumed for common statistical procedures, we used nonparametric Kruskal-Wallis one-way analysis of variance (ANOVA) models to evaluate differences based on village, gender, education level, and membership status within farmer groups. This was carried out for the following dependent variables: (i) ranking of soil fertility variables; (ii) preferences regarding soil fertility indicators; and (iii) general perceived effects of shade trees on soil fertility and cocoa. Similarly, we used a nonparametric Kruskal-Wallis ANOVA to test for significant differences in farmers' responses regarding the perceived effects of different shade trees species on soil and cocoa characteristics. All analyses were carried out using SPSS software for Windows (version 22.0.0).

\section{RESULTS}

\section{Respondent characteristics}

Out of 72 interviewed farmers, $68 \%$ were male and $32 \%$ were female. Farmer age ranged from 25 to 70 years old, with a mean age of 44 years (Table 1). Eighty-five percent of respondents 
Table 2. Ranking of soil fertility indicators considered as the most important for cocoa cultivation by respondents in Southeast Sulawesi $(n=72)$ and commonly reported describing factors of a good soil for cocoa cultivation. The ranking ranges from 1 (most frequently ranked as most important) to 7 (least frequently ranked as most important).

\begin{tabular}{|c|c|c|c|c|c|c|c|c|c|}
\hline \multirow{2}{*}{$\frac{\text { Ranking }}{1}$} & \multirow{2}{*}{$\begin{array}{l}\text { Soil fertility indicators } \\
\text { Soil structure }\end{array}$} & \multicolumn{8}{|c|}{ Description of good soil for cocoa cultivation for each indicator } \\
\hline & & Loose & $72 \%$ & Medium: & $24 \%$ & Hard & $4 \%$ & & \\
\hline 2 & Thickness of litter layer & Thick layer & $51 \%$ & Thin layer & $36 \%$ & None & $13 \%$ & & \\
\hline 3 & Macrofauna & Some & $49 \%$ & Many & $43 \%$ & None & $8 \%$ & & \\
\hline 4 & Soil color & Black-brown & $88 \%$ & Yellow-white & $10 \%$ & Red & $3 \%$ & & \\
\hline 5 & Water-holding capacity & Low & $61 \%$ & None & $38 \%$ & High & $1 \%$ & & \\
\hline 6 & Soil texture & Gritty/sandy & $40 \%$ & Smooth/silty & $49 \%$ & Sticky/clayey & $18 \%$ & Don't know & $1 \%$ \\
\hline 7 & Stone content & Some & $53 \%$ & None & $39 \%$ & Many & $6 \%$ & Depends & $3 \%$ \\
\hline
\end{tabular}

reported completing at least a primary-level education; $6 \%$ reported having received no formal education. Most farmers owned less than 5 ha of land $(82 \%)$ and were members of local farmer associations $(74 \%)$. Respondents in Wonuahoa had on average fewer years of experience in farming cocoa than those in other villages (Table 1). Ninety-seven percent of farmers reported that they owned their land, although formal aspects of land ownership varied significantly among villages. In Simbune and Asinua Jaya, most farmers inherited their land, whereas in other villages, land was mostly purchased.

\section{Farmer perceptions regarding soil fertility indicators}

Soil structure, thickness of litter layer, soil macrofauna content, and soil color were identified as the most important indicators for soil fertility (Table 2). Although we asked farmers about general macrofauna contents, most respondents focused on the presence of "worms" (cacing) for this indicator. When asked about soil structure, respondents differentiated between "looseness" (tanah gembur) and "hardness" (tanah keras). Farmers expressed clear preferences for looser, dark soils and for medium-to-thick litter layers, and "worm" presence within their plots (Table 2). We observed no significant variation in farmers' perceptions of soil fertility according to gender or farmer group membership (data not shown). Farmers with highest education levels reported a preference for darker soils $(H=8.4, p=0.04)$. Although there were no significant differences in ranking of important fertility indicators between villages, there were significant differences between villages in the ways farmers evaluated soil fertility based on litter content $(H=13.9, p=0.02)$ and stone $($ batu $)$ content $(H$ $=12.1, p=0.03$ ). In the three villages of Kolaka district, at least $50 \%$ of interviewed farmers preferred high litter contents on their farms, whereas in communities located in Konawe district, at least $50 \%$ preferred having either low litter contents or no litter at all. In Lawonua, all respondents except one indicated stone content as a positive indicator for soil fertility, whereas in Wonuahoa and Asinua Jaya, $58 \%$ and $67 \%$, respectively, of farmers indicated stone content as a negative indicator.

\section{Shade tree benefits for soil fertility}

Shade trees were perceived to modify soil fertility through several positive mechanisms or processes: by providing shade and protection (58\% of respondents), through litter fall and resulting nutrient inputs $(42 \%)$, through root systems $(22 \%)$, and by regulating soil moisture $(13 \%)$. Fifteen percent of respondents indicated that they did not know about such mechanisms. Responses were not associated with differences in community, gender, education levels, or farmer group membership (data not shown).
A detailed assessment of farmer responses indicated a good understanding of potential effects of shade trees on soil fertility indicators (Table 3). Farmers perceived significant differences between shade tree species in their effects on soil structure $(H=$ $35.5, p<0.001)$. Gliricidia was associated with beneficial effects on soil structure by $65 \%$ of respondents (Fig. $2 a$ ). Ten farmers perceived gliricidia leaves to be beneficial as compost, and 12 farmers perceived gliricidia to have a positive effect on soil moisture. Rambutan and langsat, on the other hand, were associated with negative effects on soil structure by $58 \%$ and $44 \%$ of respondents, respectively. Perceived disadvantages of rambutan and langsat were related to soil compaction and structure, as many farmers observed "harder" soils under these species, and both species were said to "eat nutrients" and contribute to water competition with neighboring cocoa trees. For mango, durian, and white teak, most respondents observed no positive or negative effects (Fig. 2).

Fig. 2. Perceptions regarding the effects of six common shade tree species on (a) soil structure; (b) soil nutrient contents; and (c) soil moisture, as reported by smallholder cocoa farmers in Southeast Sulawesi $(n=72)$.

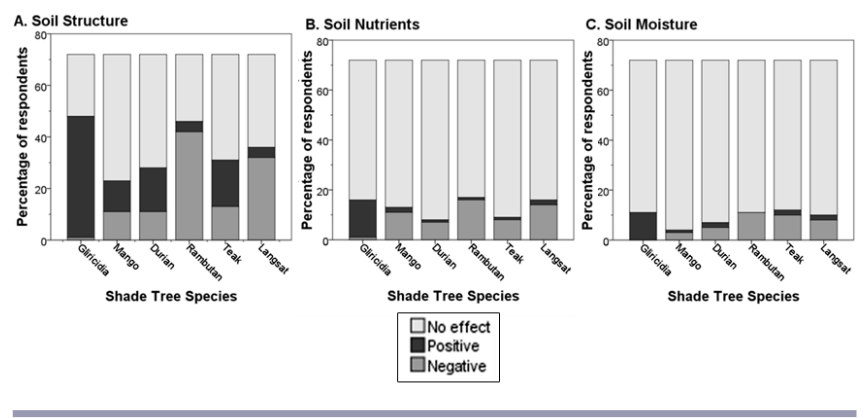

\section{Shade tree benefits for Theobroma cacao}

Shade trees were perceived to influence neighboring cocoa trees through the following mechanisms or processes: providing shade and protection ( $67 \%$ of respondents), impacting cocoa tree health and growth (34\%), affecting cocoa pod development and yields $(26 \%)$, affecting nutrient availability for cocoa trees $(22 \%)$, changing pest and disease occurrence $(17 \%)$, and regulating water and nutrient availability for cocoa trees $(8 \%)$. Fifteen percent of respondents indicated that they did not know about such mechanisms. Between villages there were significant differences in farmer perceptions of tree effects on shade protection $(H=$ 
Table 3. Selection of responses from smallholder cocoa farmers selected in six communities of Southeast Sulawesi, detailing their understanding of (a) soil fertility indicators; and (b) the links among shade trees, soil fertility, and cocoa tree development.

\begin{tabular}{|c|c|c|c|}
\hline & In line with current scientific knowledge & Established scientific knowledge and references & $\begin{array}{l}\text { No direct match with current scientific } \\
\text { knowledge }\end{array}$ \\
\hline \multicolumn{4}{|c|}{ (a) Soil fertility indicators } \\
\hline $\begin{array}{l}\text { Water-holding } \\
\text { capacity }\end{array}$ & $\begin{array}{l}\text { "too much water is bad for plants" } \\
\text { "it's better if water just passes through" }\end{array}$ & $\begin{array}{l}\text { Ideal conditions for plant growth occur when there is } \\
\text { adequate aeration in soil pore space (e.g., no waterlogging) } \\
\text { and adequate drainage. } \\
\text { e.g., Brady and Weil } 2013\end{array}$ & $\begin{array}{l}\text { "too much water makes pods turn red" } \\
\text { "no water is better" }\end{array}$ \\
\hline Worm content & $\begin{array}{l}\text { "worms eat soil litter and loosen the soil" } \\
\text { "worms lead to more bacteria," and a lot of } \\
\text { soil "bacteria are good" } \\
\text { "litter increases worm content" }\end{array}$ & $\begin{array}{l}\text { Earthworms can contribute to decomposition and } \\
\text { mineralization of soil organic matter in plant litter, } \\
\text { improved soil porosity and aggregation, and the } \\
\text { stimulation of microbial activity. } \\
\text { e.g., Blouin et al. 2013; }\end{array}$ & $\begin{array}{l}\text { "black ants are good, but cacao doesn't like } \\
\text { worms" }\end{array}$ \\
\hline Soil color & $\begin{array}{l}\text { "darker soils indicate healthier soils" } \\
\text { "soil color, litter layer and soil texture should } \\
\text { be friends [synchronized with each other]" }\end{array}$ & $\begin{array}{l}\text { Soil color is an indicator of soil characteristics and can be } \\
\text { influenced by organic matter, water contents, etc. } \\
\text { e.g., Brady and Weil 2013; }\end{array}$ & $\begin{array}{l}\text { "white soil gets very hard if it doesn't rain" } \\
\text { "red soil is bad for cacao-branches tend to } \\
\text { die" }\end{array}$ \\
\hline Stone content & $\begin{array}{l}\text { "the soil tends to be looser if there are no } \\
\text { stones" } \\
\text { "stones disturb cacao roots" }\end{array}$ & $\begin{array}{l}\text { Stony soils have been considered as unsuitable for cocoa. } \\
\text { e.g., Ruf et al. } 1998\end{array}$ & $\begin{array}{l}\text { "some stones are good because stones cool the } \\
\text { soil" } \\
\text { "it's good for cacao if there are some stones-- } \\
\text { this means that the cacao will get heavier pods" }\end{array}$ \\
\hline Litter content & $\begin{array}{l}\text { "many leaves are good for the little roots of } \\
\text { the cacao tree which come up to take food } \\
\text { from the leaves" } \\
\text { "litter can hold water in the soil and cool it" } \\
\text { "humus is a sort of fertilizer and replaces } \\
\text { chemical fertilizer" }\end{array}$ & $\begin{array}{l}\text { A thick layer of litter and organic residues can contribute } \\
\text { to decreased nutrient leaching in areas characterized by } \\
\text { high rainfall. } \\
\text { e.g., Beer et al. 1988; } \\
\text { Soil organic matter decomposition provides substrates for } \\
\text { microbial activity, and humus increases a soil's capacity to } \\
\text { store plant-available nutrients. } \\
\text { e.g., Brady and Weil 2013; }\end{array}$ & $\begin{array}{l}\text { "litter makes new pods in the cacao" } \\
\text { "it's better if the soil is clean under the cacao } \\
\text { tree before fertilizer is applied so that there is no } \\
\text { reaction with fertilizer" }\end{array}$ \\
\hline Soil texture & $\begin{array}{l}\text { "clay soil gets too dry and hard and kills } \\
\text { cacao" } \\
\text { "soils that are too sandy or too sticky [clayey] } \\
\text { are not ideal for plants" }\end{array}$ & $\begin{array}{l}\text { Clay soils have a high nutrient-holding capacity but can get } \\
\text { too sticky when wet or too hard for cultivation when they } \\
\text { are dry. Sandy soils have lower nutrient-holding capacity } \\
\text { and do not hold soil moisture well. } \\
\text { e.g., Brady and Weil 2013; }\end{array}$ & $\begin{array}{l}\text { "if the soil is too clayey, there will be a lot of } \\
\text { cacao leaves but no pods" }\end{array}$ \\
\hline Soil consistency & $\begin{array}{l}\text { "loose soil is good for cacao roots which are } \\
\text { able to spread more easily" }\end{array}$ & $\begin{array}{l}\text { Loose "granular" noncompacted soil structure allows for } \\
\text { good plant root development } \\
\text { e.g., Brady and Weil 2013; }\end{array}$ & $\begin{array}{l}\text { "while looser soil can be healthier, in the dry } \\
\text { season harder soils keep in nutrients better" }\end{array}$ \\
\hline & In line with current scientific knowledge & Established scientific knowledge and references & $\begin{array}{l}\text { No direct match with current scientific } \\
\text { knowledge }\end{array}$ \\
\hline \multicolumn{4}{|c|}{ (b) Links among shade trees, soil fertility, and cocoa tree development } \\
\hline $\begin{array}{l}\text { Shading and } \\
\text { protection }\end{array}$ & $\begin{array}{l}\text { "when cacao is young it needs shade, when it } \\
\text { gets older it doesn't need shade anymore" } \\
\text { "shade trees cool down and loosen the soil" } \\
\text { "too much shade and too little shade are both } \\
\text { bad" } \\
\text { "there is a connection between too much } \\
\text { shade and black pods" }\end{array}$ & $\begin{array}{l}\text { Shade trees compete with neighboring plants (e.g., cocoa } \\
\text { trees) for growth resources but may also provide benefits } \\
\text { such as microclimate amelioration or improved soil } \\
\text { structure / fertility. } \\
\text { e.g, Hartemink et al. } 2005 \text {; Belsky et al. 1989; } \\
\text { Young cocoa seedlings are generally established under } \\
\text { denser shade which is then removed as the cocoa trees } \\
\text { mature. } \\
\text { e.g., CRIG Ghana Cocoa Manual; } \\
\text { Black pod infection in cocoa trees is generally exacerbated } \\
\text { by high humidity and poor airflow (e.g., under heavy } \\
\text { shade). }\end{array}$ & $\begin{array}{l}\text { "the leaves of durian, mango and langsat are } \\
\text { hard to decompose" } \\
\text { "if shade trees are too close, branches can fall } \\
\text { on cacao and kill it" }\end{array}$ \\
\hline $\begin{array}{l}\text { Cocoa tree } \\
\text { health }\end{array}$ & $\begin{array}{l}\text { "shade trees can improve cacao leaf growth" } \\
\text { "Shade tree litter provides food for cacao } \\
\text { trees" }\end{array}$ & $\begin{array}{l}\text { e.g., Beer 1987; World Cocoa Foundation Cocoa Manual; } \\
\text { Shade trees might improve crop (e.g., cocoa) phenology } \\
\text { through improvement of microclimatic conditions. They } \\
\text { might also contribute to soil fertility through increased } \\
\text { SOM from litterfall or improved nutrient recycling. } \\
\text { e.g., Beer 1987; }\end{array}$ & $\begin{array}{l}\text { "cacao and shade trees should be the same age } \\
\text { as this balances the soil" } \\
\text { "cacao pods are harder under rambutan" } \\
\text { "durian and mango don't match with cacao" } \\
\text { "under rambutan and langsat, cacao trees get } \\
\text { yellow leaves" }\end{array}$ \\
\hline $\begin{array}{l}\text { Shade tree } \\
\text { roots }\end{array}$ & $\begin{array}{l}\text { "shade tree roots can disturb cacao trees" } \\
\text { "shade tree roots improve water-holding } \\
\text { capacity" } \\
\text { "hold together the soil" } \\
\text { "brings vitamin to other plants" } \\
\text { "roots make competition for nutrients" }\end{array}$ & $\begin{array}{l}\text { Shade tree roots can improve soil drainage and aeration, or } \\
\text { recycle nutrients not available to crops (e.g., cocoa). } \\
\text { e.g., Beer 1987; van Noordwijk and Purnomosidhi 1995; } \\
\text { Shade tree roots can compete for moisture or nutrients with } \\
\text { crops (such as cocoa). } \\
\text { e.g., Beer 1987; }\end{array}$ & $\begin{array}{l}\text { "gamal [gliricidia] roots have oxygen in them } \\
\text { and provide it to the cacao" } \\
\text { "the farmer can change soil fertility conditions } \\
\text { but the tree can't" } \\
\text { "shade tree roots harden the soil" } \\
\text { "the shade tree trunk affects soil water-bigger } \\
\text { trunks mean drier soils" } \\
\text { "rambutan takes water through its long roots" } \\
\text { "langsat can change soil pH" }\end{array}$ \\
\hline $\begin{array}{l}\text { Pest and } \\
\text { disease }\end{array}$ & $\begin{array}{l}\text { "shade trees attract more birds, which can } \\
\text { reduce pest and disease" } \\
\text { "shade trees increase the risk of black pod } \\
\text { [fungus] infection" }\end{array}$ & $\begin{array}{l}\text { Shade trees can reduce pest and disease incidence through } \\
\text { increases in natural enemies } \\
\text { e.g., Beer } 1987 \text { Pumarino et al. } 2015 \text {; } \\
\text { Black pod infection in cocoa trees is generally exacerbated } \\
\text { by high humidity and poor airflow (e.g., under heavy } \\
\text { shade). } \\
\text { e.g., Beer 1987; World Cocoa Foundation Cocoa Manual; }\end{array}$ & $\begin{array}{l}\text { "rambutan attracts wild pigs" } \\
\text { "rambutan attracts too many worms" } \\
\text { "rambutan worms go to cacao; cacao worms go } \\
\text { to durian" }\end{array}$ \\
\hline
\end{tabular}


12.6, $p=0.03)$ and yields $(H=13.0, p=0.02)$. In Tasahea, Andowengga, and Lawonua, most farmers associated shade trees with increased canopy protection, whereas in the other villages, less than $50 \%$ of farmers reported this. Wonuahoa was the only village where no respondents reported associations between shade trees and cocoa yields. We found no differences in responses related to education levels, gender, or farmer group membership status (data not shown).

Farmers perceived significant differences between shade tree species in their effects on shade protection $(H=29.8, p<0.001)$, pest and disease occurrence $(H=18.6, p=0.002)$, and yields $(H$ $=16.6, p=0.005)$. Gliricidia was associated with an increase in cocoa yields by $21 \%$ of respondents, whereas all other species were associated with decreased yields by $22-58 \%$ of respondents (Fig. 3a). Most farmers perceived shade trees to have no effects on cocoa tree growth (Fig. $3 b$ ) or pest and disease occurrence (Fig. $3 c$ ), although mango, durian, and rambutan were reported to increase pest and disease occurrence more frequently than other species. The shade provided by gliricidia and durian, respectively, was perceived to be beneficial for cocoa trees by $39 \%$ and $21 \%$ of respondents, whereas the shade provided by mango and white teak was, respectively, reported by $22 \%$ and $24 \%$ of farmers to have negative effects on cocoa (Fig. 3d). Twenty-eight percent of respondents pointed out the importance of pruning gliricidia properly and recognized that excessive shade caused by insufficient pruning could lead to both decreased cocoa yields and decreased cocoa tree health and black pod infections.

Fig. 3. Perceptions regarding the effects of six common shade tree species on (a) cocoa yields; (b) cacao tree health; (c) shade protection; and (d) pest and disease occurrence, as reported by smallholder cocoa farmers in Southeast Sulawesi $(n=72)$.
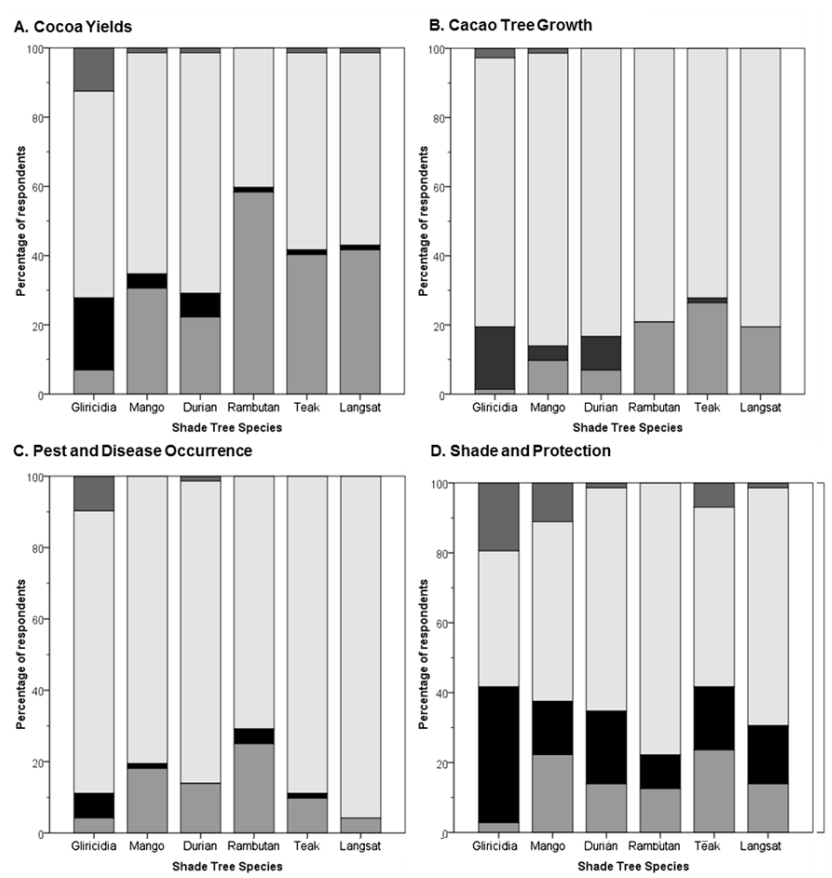

Of the $97 \%$ of respondents who had gliricidia in their plots, only two did not plant it there themselves. For the other species, $85 \%$ of respondents planted durian, 75\% planted rambutan, $68 \%$ planted mango, $57 \%$ planted langsat, and $47 \%$ planted white teak in their cocoa plots. A smaller proportion of farmers reported avoiding planting some tree species because they disliked them: $24 \%$ for mango, $21 \%$ for rambutan, $39 \%$ for white teak, and $14 \%$ for langsat. Other desirable shade trees commonly mentioned by participants were Musa musa or banana (26\% of respondents), Cocos nucifera or coconut (17\%), and Hevea brasiliensis or rubber $(4 \%)$.

\section{Shade trees as additional income sources}

In addition to shade protection, farmers reported various uses for the shade tree species included in our questionnaire. Gliricidia trees were used as pepper stakes by $63 \%$ of respondents and for firewood by $58 \%$. A majority of respondents indicated that crops from fruit-bearing shade tree species were used primarily for household consumption: mango (67\% of respondents), durian $(85 \%)$, rambutan $(81 \%)$, and langsat $(81 \%)$. These same crops were also sold to supplement household incomes. White teak was used as construction material by $43 \%$ of respondents and was cited as a supplemental source of household income by $17 \%$ of respondents (Fig. 4).

Fig. 4. Reported alternative uses for six common shade tree species found in cocoa agroforests in southeast Sulawesi. The values shown are cumulative, as respondents often cited more than one use per tree.

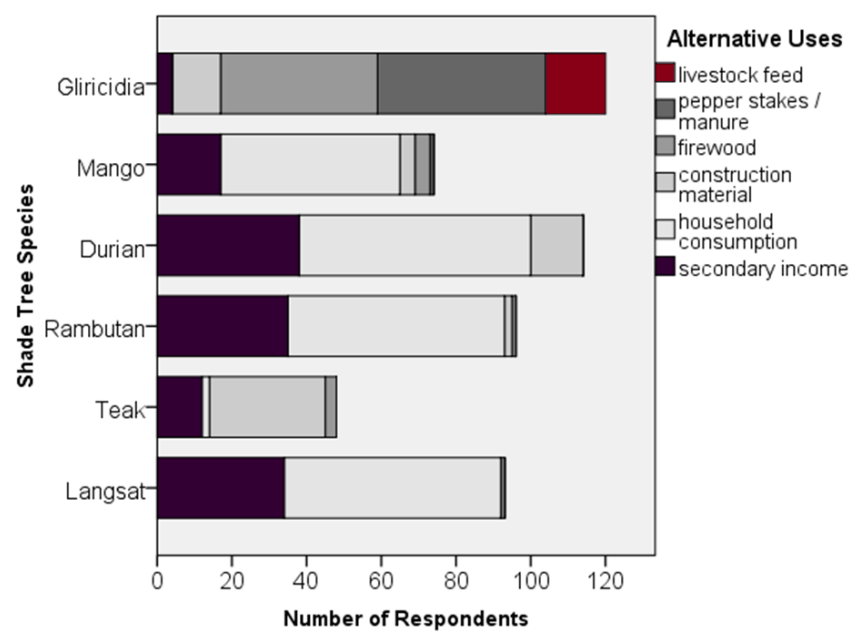

When asked about alternative income sources to cocoa production, farmers frequently referred to some of the shade tree uses mentioned above. The most commonly cited additional income sources were the cultivation of other crops, which included pepper (54\% of respondents), fruit and vegetables intercropped with tree crops $(19 \%)$, patchouli intercropped with tree crops $(15 \%)$, and annual crops (maize or rice) $(14 \%)$. Seven percent of respondents reported livestock as an additional income source. In Asinua Jaya, logging from the forest was an important livelihood source (personal observation), although due to the illegal nature of this activity only five farmers admitted openly that it contributed to their incomes. In Lawonua, three farmers reported that working on large palm oil plantations was the most 
important income source in their households. Farmers reported that these other income sources often contributed more to their household income than revenues from cocoa production.

\section{Factors influencing fertilizer use}

Fifty-four percent of farmers reported using a mix of both chemical and organic fertilizer (which generally consisted of green manure and compost). Twenty-one percent of farmers used only chemical fertilizer, $15 \%$ used only organic fertilizer, and 10\% used no fertilizer. Farmers associated organic fertilizer with positive effects on soil (39\% of respondents), whereas chemical fertilizer was perceived to have positive effects on soil by $17 \%$ of respondents and negative effects by 19\% (Fig. $5 a$ ). In contrast, $56 \%$ of respondents cited the positive effects of chemical fertilizer on cocoa yields compared with $17 \%$ for organic fertilizer (Fig. $5 b)$. More farmers found that organic fertilizer was more accessible and affordable compared with chemical fertilizer (Fig. $5 c$ ). Few farmers cited convenience of use as a factor determining which kind of fertilizer they preferred (Fig. 5d). Sixteen farmers reported using organic fertilizer after receiving external guidelines, whereas only four farmers reported using chemical fertilizer because of external information.

Fig. 5. Perceptions of chemical and organic fertilizer in terms of (a) effect on soils; (b) effect on cocoa yields; (c) market and cost accessibility; and (d) convenience and efficiency of use, as reported by smallholder cocoa farmers in Southeast Sulawesi ( $n$ $=72$ ).
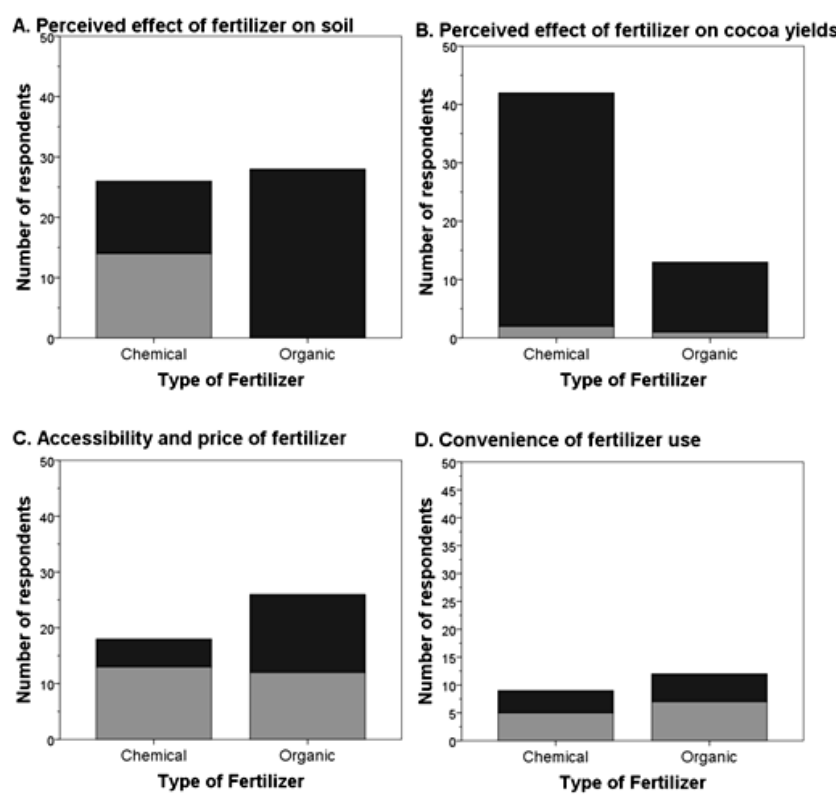

Perception

Positive

$\square$ Negative

External farm management guidelines predominantly originated from government programs, although local farmer networks and AgFor also played an important role (Table 4). Only 7\% of respondents reported receiving no information on the addressed topics. Less advice was received about shade tree management practices than about shade tree selection, planting densities, and fertilizer application (Table 4).

\section{Limiting factors for cocoa production}

The factors constraining cocoa production most often mentioned were: crop damage due to pests and disease ( $93 \%$ of respondents), low cocoa selling prices $(32 \%)$, decreased tree productivity $(28 \%)$, aging cocoa trees $(24 \%)$, unfavorable weather conditions $(19 \%)$, and soil degradation ( $8 \%$ ) (Fig. 6).

Fig. 6. Commonly reported constraints that negatively impacted cocoa production in smallholder plots in 2014-2015 in six communities of Southeast Sulawesi.

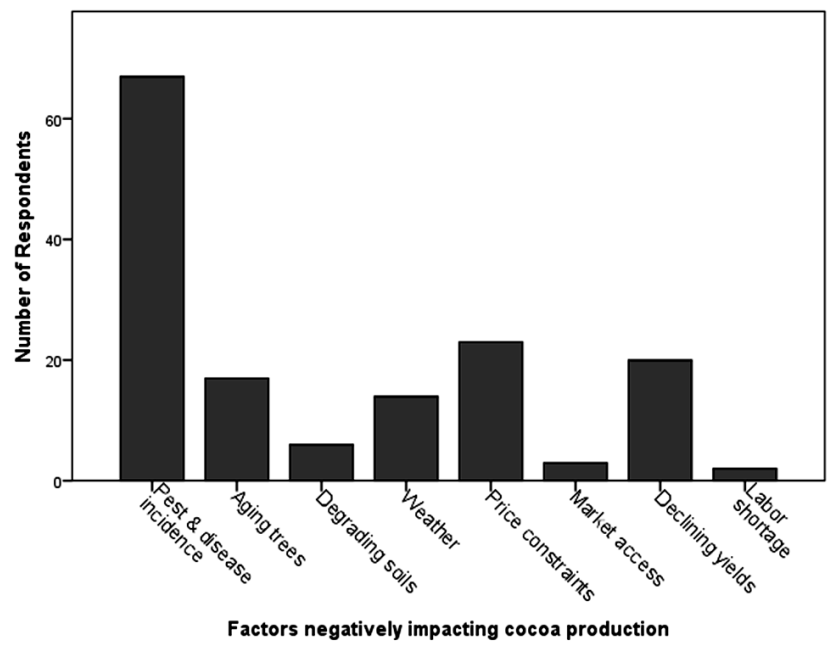

\section{DISCUSSION}

Farmers' knowledge about soil fertility and soil-tree-cocoa interactions

Respondents in our study reported using soil physical properties (structure and color) and biological properties (quantity of litter and "worms") as indicators of soil fertility. Smallholders expressed a clear preference for dark, loose soils, which echoes previous farmer knowledge assessments in West African cocoa agroforests (Talawar and Rhoades 1998, Isaac et al. 2009, Dawoe et al. 2012). In general, farmers' assessments of soil fertility were consistent with existing literature (Table 3 ). Farmers frequently associated different soil properties, such as high litter contents and increased soil nutrients and "worm" contents (Table 3). Overall, our findings echo those of previous assessments (e.g., Saito et al. 2006) and suggest that farmers in the study region possessed a holistic understanding of the mechanisms linking soil properties in the context of cocoa cultivation. Local knowledge about the interactions among shade trees, soil fertility, and neighboring cocoa trees was similarly in line both with previous studies of farmer perceptions of tree-crop interactions (e.g., Albertin and Nair 2004, Anglaaere et al. 2011) and with scientific literature (Table 3). Farmers recognized shade trees' dual effects in cocoa agroforests, acknowledging the benefits provided by shade trees, including microclimate regulation and increased organic inputs from litterfall, as well as disadvantages related to increased resource competition with neighboring cocoa trees. 
Table 4. Proportion of smallholder farmers interviewed in Southeast Sulawesi $(n=72)$ who reported receiving knowledge or advice about the topics of shade tree selection, shade tree management, planting densities, and fertilizer application.

\begin{tabular}{|c|c|c|c|c|c|c|}
\hline \multirow[t]{2}{*}{ Knowledge topic } & \multicolumn{5}{|c|}{ Source of knowledge } & \multirow{2}{*}{$\begin{array}{c}\text { No knowledge exchange } \\
\text { reported }\end{array}$} \\
\hline & Farmer group & $\begin{array}{l}\text { AgFor } \\
\text { (ICRAF) }\end{array}$ & Other NGOs & Government & Other & \\
\hline Shade tree selection & $38 \%$ & 19 & $3 \%$ & $43 \%$ & $4 \%$ & $22 \%$ \\
\hline Shade tree management & $26 \%$ & $14 \%$ & $1 \%$ & $32 \%$ & $10 \%$ & $39 \%$ \\
\hline Planting densities & $38 \%$ & $18 \%$ & $4 \%$ & $42 \%$ & $8 \%$ & $24 \%$ \\
\hline Fertilizer application & $32 \%$ & $18 \%$ & $3 \%$ & $40 \%$ & $8 \%$ & $24 \%$ \\
\hline
\end{tabular}

At times, respondents considered indicators not commonly addressed by scientific studies (Table 3 ). This has been the case in other regions where farmers were acutely aware of processes directly tied to crop productivity, such as the risk of physical damage caused to cocoa trees by falling branches from shade trees (Atkins and Eastin 2012, Lamond et al. 2016) or the appearance of yellow leaves, which are indicative of poor cocoa tree health and can be expected to lead to decreased productivity (Isaac et al. 2009). Similarities in farmer perceptions regarding physical soil properties (Joshi et al. 2004) and the usefulness of shade trees in coffee or cocoa agroforests (Albertin and Nair 2004, Anglaaere et al. 2011, Gyau et al. 2014) have been observed across different regions. Such commonalities in the ways cocoa farmers across the globe relate soil fertility and cocoa tree health highlight that indicators used by farmers vs. scientists do not always capture the same things, and underline the importance of local knowledge. This is acknowledged by more inclusive forms of "integrated natural resource management" approaches that assign more value to local knowledge than other approaches (e.g., van Noordwijk 2017).

\section{Farmers' knowledge can complement quantitative data from biophysical studies}

Despite significant overlap between local and scientific knowledge, farmer perceptions sometimes diverged from established scientific knowledge. Farmer understanding of the influence of soil quality on cocoa productivity did not match common biophysical findings (Table 3). Our data further indicated contrasting views and perceptions among different farmers regarding the effects of shade trees on soil fertility. For example, some farmers cited preferring high amounts of litter, whereas others preferred none (Tables 2,3). Such differences could be related to knowledge gaps in farmers' understanding of nutrient cycling processes. Alternatively, as discussed above, they might be indicators for underlying biophysical processes not always captured by formal science. For instance, our data showed significant differences among the six selected communities regarding respondents' reported prioritization of soil indicators. Farmers in Lawonua had a different perception of stone content in their soils than other farmers. Such differences have previously been linked to variation in environmental conditions (Halbrendt et al. 2014, Meijer et al. 2015), and we similarly found that the community of Lawonua is located in a floodplain with dystric fluvisols, whereas other villages are located in more hilly areas characterized by orthic acrisols (FAO 1979). Farmer preferences might reflect differences in soil conditions at the landscape level relating to sedimentation and weathering processes (van Straaten
2006, Brady and Weil 2013). More generally, these examples highlight how farmers' knowledge and perceptions can help researchers interpret data within a given context and thus contribute to a more nuanced understanding of agroecological interactions.

A high proportion of respondents associated shade trees with a measurable decrease in cocoa yields, citing excessive shade and resource competition as explanations for this negative interaction. Farmers moreover expressed preferences for certain species over others - in particular, gliricidia, which was associated with yield improvements. These results only partially align with those from an observational study conducted by Wartenberg et al. (unpublished manuscript) in the community of Wonuahoa, which showed a marginally significant increase of average cocoa yields under gliricidia, but also found that on average, individual shade trees of various species (gliricidia, rambutan, durian, mango, white teak, and langsat) increased soil fertility and had no significant effect on cocoa yields. The authors specifically selected isolated shade trees in cocoa agroforests, whereas farmers in our study focused on the cumulative effects of certain species in their plots. We postulate that the effect of shade trees might vary at different scales or at different planting densities, and that positive or negative effects of individual shade trees do not always scale up at the farm level (Wartenberg et al. 2017).

Wartenberg et al. (unpublished manuscript) found the highest increases in soil fertility under rambutan, whereas farmers in our surveys perceived rambutan to have a mostly negative effect on soil fertility. Most respondents in our case study associated rambutan (and langsat) with soil hardening (Fig. $2 a$; Table 3 ). In contrast, a comparison of changes in soil bulk density and moisture contents under shade trees showed no changes under rambutan and significant improvements in soil moisture and bulk density under langsat (Appendix 1). Such discrepancies between local and scientific knowledge are not unusual (e.g., Gray and Morant 2003) and, in this case, might be related to farmers' strong associations between the physical appearance of root systems and the perceived effects on soil quality. In Southeast Sulawesi, respondents described the root structure of rambutan and langsat trees as "long," "strong," "shallow," or "spreading," in line with existing literature (Watson 1982, Calvo 1994, van Noordwijk and Purnomosidhi 1995). Smallholders tend to associate visible root systems with an increase in resource competition between shade trees and crops, as has been documented previously in both Java (Joshi et al. 2000) and Nepal (Joshi et al. 2004). Farmers might also underestimate the extent to which rambutan or durian can improve soil indicators that we used to assess soil fertility. 
Generally, the farmers that we surveyed tended to possess a good understanding of ecosystem components and processes directly visible to the naked eye, such as litter decomposition or worm activity (Talawar and Rhoades 1998). However, farmer understanding of less visible processes, such as microbial activity or nitrogen fixing through root nodules, is often less accurate (e.g., Grossman 2003, Joshi et al. 2004). Additionally, the proportion of farmers that associated gliricidia with increased cocoa yields was significantly lower than the number of farmers who recognized the positive effects of gliricidia on soil fertility (Figs. 2, 3a). As this was not the case for other species, we postulate that farmers' strong positive perception of gliricidia may have been influenced by external knowledge sources.

\section{Socioeconomic factors influencing local knowledge}

We found clear distinctions across the six communities selected for this study in terms of represented ethnicities (Janudianto et al. 2012). In Southeast Sulawesi, significant differences have been reported between Tolaki or Bugis households regarding local knowledge and perceptions about cocoa farm management. As a consequence of migration dynamics, increased communication between both ethnic groups has been shown to strongly influence cocoa cultivation approaches (Weber et al. 2007, Mulyoutami et al. 2015). We postulate that farmers who migrated to Southeast Sulawesi from other islands (e.g., Java or Bali) might similarly arrive with differing experiences and assumptions than farmers from Southeast Sulawesi.

Contrary to common expectations and results found elsewere (e.g., Mulyoutami et al. 2015), in this study, gender of the respondents was not found to be a differentiating factor for farmers' perceptions and management of soil fertility, shade trees, or their interactions. Women in the study area were generally directly involved in day-to-day farm management activities alongside men, which may have contributed to information sharing and lack of discernible differences in perception according to gender. However, our sample size may also have been too limited to draw stronger conclusions from obtained data.

Local knowledge is also strongly influenced by information derived from external sources (Martini et al. 2017). Farmers did report that information received on the addressed topics mainly originated from short-term government programs, other farmers, and to some extent, AgFor project extension agents (Table 4). The Indonesian government has provided targeted support of cocoa projects in the region since the 1980s through projects like the Program Gerakan Nasional Percepatan Revitalisasi Kakao (GERNAS) seedling program (Martini et al. 2013). More recently, ICRAF's AgFor project activities included extensive training and knowledge exchange activities for cocoa farmers.

Nevertheless, the existence of long-term frameworks and policies regulating agroforestry establishment, management practices, or availability of incentive schemes, currently remains very limited in Southeast Sulawesi. External nongovernmental organization (NGO) activity similarly remains very limited in the area. Strengthening government-led extension services and programs should, therefore, be considered an important focal point for future knowledge transfer, and ultimately, the adoption of more sustainable farming practices. Similarly to Martini et al. (2013), we found that formal schooling or training was not cited as a source of information about farming management. Therefore, it was not surprising that we found no relationship between educational level and local knowledge about soil-treecrop interactions and management practices. However, according to our results, information was also transferred through informal exchanges between local farmer groups and through AgFor/ ICRAF agents during practical field activities. This echoes the findings originating from the same study area presented in Martini et al. (2017) and indicates that both of these groups represent important entry points for future knowledge transfer.

\section{Knowledge and perception can impact farmers' management decisions}

Farmer use of fertilizers in Sulawesi illustrates the extent to which farmer knowledge and perceptions of ecosystem processes can influence management decisions (Fig. 5). A significant proportion of interviewed farmers were aware of the benefits of organic fertilizer in terms of long-term soil health, accessibility, affordability, and efficiency. Respondents also demonstrated awareness of the negative effects of chemical fertilizer on longterm soil fertility (through "hardening" of the soil), although chemical fertilizers were also perceived to have a more positive and "faster" effect on cocoa yields by directly providing "food for cocoa trees." Although more farmers applied only chemical fertilizers $(21 \%)$ compared with those who applied only organic fertilizer (15\%), it was notable that most farmers (54\%) tried to address perceived trade-offs between organic and chemical fertilizer use by applying a mix of both in their plots.

Respondents in our study were thus receptive to the adoption of more "ecologically" oriented solutions where relevant, particularly if these were perceived to be directly linked to increased crop production and incomes. This finding supports the notion that farmers in tropical forest frontiers are aware of shortand long-term trade-offs associated with farm management decisions (e.g., van Noordwijk 2017). Socioeconomic factors such as income or farm size have been shown to directly influence farmers' abilities to prioritize short- vs. long-term benefits in Sulawesi (Sabastian et al. 2017), further adding to the complexity of farmers' decision-making processes. Greater recognition of the value of flexible conservation farming approaches is needed, as these can encourage individual farmers to minimize trade-offs by tailoring the way they integrate sustainable and "conventional" management practices to fit their needs. Such approaches could increase adoption rates and encourage simultaneous mitigation of long-term soil depletion and prioritization of crop productivity to support farmers' livelihoods (Swift et al. 2004, Tscharntke et al. 2011, Mbow et al. 2014).

Wartenberg et al. (unpublished manuscript) found that the effects of gliricidia on soil fertility in cocoa agroforests were only marginally significant when compared with other species, such as rambutan. However, respondents in our study tended to associate gliricidia with positive effects not only on cocoa yields but also on cocoa tree growth and general soil fertility, seemingly overestimating the benefits of gliricidia. Gliricidia and other nitrogen-fixing trees have been actively promoted by both government- and project-based extension programs since the 
1980s and 1990s, based on their capacity to improve soils and thus positively influence smallholder farming systems (Roshetko 2001). Such policies, combined with gliricidia's good local performance, likely contributed to farmers' overestimation of the species' positive impact. To some extent, reported farmer preferences were directly reflected in planting choices at our field sites, as gliricidia was the species most commonly interplanted with cocoa trees.

Surprisingly, although other species like rambutan or mango were often associated with negative effects on soils and cocoa, more than half of respondents still chose to plant individuals of these species on their plots. Both species were reported to contribute to household incomes, suggesting that the inclusion of specific shade tree species in cocoa plots is still primarily driven by economic considerations. This confirms the results of Rahmanulloh et al. (2012), who reported higher total income for mixed cocoa systems compared with monoculture cocoa in Sulawesi. The existence of such economic incentives for diverse shade tree inclusion is encouraging. Nevertheless, at present, the inclusion of individual shade trees does not scale up systematically at the farm or landscape level, and low-diversity cocoa systems remain prevalent in Sulawesi despite general consensus across formal literature regarding the benefits of increased biodiversity in cocoa agroforests (e.g., Tscharntke et al. 2011).

\section{Adoption barriers to more widespread shade tree diversification in Southeast Sulawesi}

According to the respondents of our study, the principal barriers to cocoa production in Southeast Sulawesi were pest and disease incidence and low cocoa selling prices (Fig. 6). Both factors can be expected to play a significant role for decision making in cocoa plot management. Nevertheless, farmers did not perceive increased tree diversification to address these barriers by decreasing pest and disease incidence, improving cocoa yields, or increasing selling prices. This lack of a direct association between shade tree diversification and yield or income improvements might be one of the principal adoption barriers for more widespread diversification at the farm level.

Although cocoa selling prices are determined by external markets, scientific evidence suggests that the diversification of agroforests might reduce yield losses from pest and disease incidence (Pumariño et al. 2015). Nevertheless, the effects of shade trees on pest and disease vectors are complex and associated with tradeoffs in terms of overall yield benefits (Schroth et al. 2000, Bos et al. 2007, Tscharntke et al. 2011). In Southeast Sulawesi, research suggests that whereas shade trees in cacao agroforests can indeed reduce the occurrence of certain pests, increased humidity under shade tree canopy may contribute to increased black pod infections in the absence of adequate pruning (Martini et al., unpublishedmanuscript). It remains unclear whether farmers'lack of recognition of the benefits of shade trees for pest and disease management (Fig. 3c) can be attributed to poor understanding of the mechanisms through which shade trees can be beneficial in this context - or simply to a lack of benefits at the farm level.

Addressing this "dual" knowledge gap through further research is crucial and needs to be linked to relevant policy and knowledge exchange initiatives. If shade trees can be managed to effectively contribute to pest and disease reduction, targeted recommendations could provide smallholders with stronger incentives to include shade trees in their farms, while also significantly contributing to their long-term income security. In the greater context of managing trade-offs between farmer well-being and biodiversity conservation, an assessment of the costs and benefits of management approaches targeting tree diversification at different scales (individual tree, individual farm, landscape) could provide valuable insights both for farmers and researchers.

\section{CONCLUSIONS}

We found that farmers' understanding of biophysical interactions in Southeast Sulawesi was comprehensive and generally aligned with science-based findings. Additionally, farmers' perceptions sometimes reflected nuances and details linked to geographical and socioeconomic context, which are not consistently addressed in formal scientific studies. These findings underline the importance of local knowledge and the role it can play in complementing or supplementing research outcomes from biophysical studies. Drawing on local expertise could benefit both researchers and local communities and contribute to farmers' empowerment. Improved integration of such localized knowledge into training curricula and extension material from governmental or other programs, including farmer-to-farmer approaches, could also have great potential in terms of increasing adoption rates of sustainable farming practices.

Smallholders in Sulawesi had a good understanding of the advantages and disadvantages associated with chemical vs. organic fertilizers and managed these trade-offs by using a combination of both types of fertilizer. Farmers similarly approached shade tree management on cocoa farms by considering different knowledge sources and evaluating shortterm and long-term trade-offs. Farmers with different income levels have different resources and priorities to consider, and our study highlights the value of flexible conservation farming approaches that can allow farmers to minimize trade-offs and develop farming practices that fit their households' needs.

Discrepancies between local perceptions of the effects of specific shade tree species within cocoa agroforests and scientific findings originating in the same study area could point to "dual knowledge gaps" either in local knowledge or in science-based literature, which remains scarce in cocoa ecosystems. Indeed, the impacts of shade tree diversification on yield outcomes at the cocoa farm level are to date still poorly documented, and further research to quantify and understand biophysical interactions determining cocoa yields is needed. We further suggest that, in addition to continued improvement of top-down policy development that addresses external socioeconomic pressures faced by smallholders, further research on the relationship between farmer knowledge and decision making remains invaluable. Low farmer awareness of direct benefits of shade tree inclusion for cocoa yields likely contributes to low adoption rates of systematic diversification practices. Identifying and addressing local knowledge gaps via targeted knowledge dissemination could potentially improve long-term adoption rates of such practices.

Responses to this article can be read online at: http://www.ecologyandsociety.org/issues/responses. php/9921 


\section{Acknowledgments:}

This research was supported by ETH Zürich, as well as by ICRAF. We would like to thank ICRAF's AgFor team in Bogor for their advice and logistical support, the AgFor Kendari and Kolaka teams and Husrin Laode for their invaluable organizational and technical support in the field, as well as Emilia Schmitt and Aimee Shrek for their insights regarding questionnaire development. We are particularly grateful to all farmers who participated in our study.

\section{LITERATURE CITED}

Albertin, A., and P. Nair. 2004. Farmers' perspectives on the role of shade trees in coffee production systems: an assessment from the Nicoya Peninsula, Costa Rica. Human Ecology 32:443-463. http://dx.doi.org/10.1023/B:HUEC.0000043515.84334.76

Anglaaere, L. C., J. Cobbina, F. L. Sinclair, and M. A. McDonald. 2011. The effect of land use systems on tree diversity: farmer preference and species composition of cocoa-based agroecosystems in Ghana. Agroforestry Systems 81:249-265. http://dx.doi. org/10.1007/s10457-010-9366-Z

Atkins, J. E., and I. Eastin. 2012. Seeing the trees: farmer perceptions of indigenous forest trees within the cultivated cocoa landscape. The Forestry Chronicle 88:535-541. http://dx.doi. org/10.5558/tfc2012-102

Barrett, C. B., and L. E. Bevis. 2015. The self-reinforcing feedback between low soil fertility and chronic poverty. Nature Geoscience 8:907-912. http://dx.doi.org/10.1038/ngeo2591

Barrios, E., and M. Trejo. 2003. Implications of local soil knowledge for integrated soil management in Latin America. Geoderma 111:217-231. http://dx.doi.org/10.1016/S0016-7061 (02)00265-3

Beer, J. 1987. Advantages, disadvantages and desirable characteristics of shade trees for coffee, cacao and tea. Agroforestry Systems 5:3-13. http://dx.doi.org/10.1007/BF00046410

Beer, J. 1988. Litter production and nutrient cycling in coffee (Coffea arabica) or cacao (Theobroma cacao) plantations with shade trees. Agroforestry Systems 7:103-114. http://dx.doi. org/10.1007/BF00046846

Belsky, A., R. Amundson, J. Duxbury, S. Riha, A. Ali, and S. Mwonga. 1989. The effects of trees on their physical, chemical and biological environments in a semi-arid savanna in Kenya. Journal of Applied Ecology:1005-1024. http://dx.doi.org/10.2307/2403708

Blouin, M., M. E. Hodson, E. A. Delgado, G. Baker, L. Brussaard, K. R. Butt, J. Dai, L. Dendooven, G. Pérès, and J. Tondoh. 2013. A review of earthworm impact on soil function and ecosystem services. European Journal of Soil Science 64:161182. http://dx.doi.org/10.1111/ejss. 12025

Bos, M. M., I. Steffan-Dewenter, and T. Tscharntke. 2007. Shade tree management affects fruit abortion, insect pests and pathogens of cacao. Agriculture, Ecosystems and Environment 120:201-205. http://dx.doi.org/10.1016/j.agee.2006.09.004

Brady, N. C., and R. Weil. 2013. Nature and properties of soils. Pearson Higher Education, London, UK.
Calvo, A. 1994. Rambutan-based intercropping system: intercropping rambutan with grain legumes and corn and their effects on its growth and yield. University of Southern Mindanao $R \& D$ Journal 3(1):39-76..

Clough, Y., V. V. Krishna, M. D. Corre, K. Darras, L. H. Denmead, A. Meijide, S. Moser, O. Musshoff, S. Steinebach, and E. Veldkamp. 2016. Land-use choices follow profitability at the expense of ecological functions in Indonesian smallholder landscapes. Nature Communications 7: 13137. http://dx.doi. org/10.1038/ncomms13137

Dawoe, E., J. Quashie-Sam, M. Isaac, and S. Oppong. 2012. Exploring farmers' local knowledge and perceptions of soil fertility and management in the Ashanti Region of Ghana. Geoderma 179:96-103. http://dx.doi.org/10.1016/j.geoderma.2012.02.015

Doran, J. W., and T. B. Parkin. 1994. Defining and assessing soil quality. Pages 3-22 in J. W. Doran, D. C. Coleman, D. F. Bezdicek, and B. A. Stewart, editors. Defining soil quality for a sustainable environment, proceedings, 4-5 November 1992, Minneapolis, Minnesota, USA. Soil Science Society of America and American Society of Agronomy, Madison, Wisconsin, USA. http://dx.doi. org/10.2136/sssaspecpub35.c1

Food and Agriculture Organization (FAO). 1979. Soil map of the world - SE Asia. FAO, Rome, Italy. [online] URL: http://www.fao. org/fileadmin/user_upload/soils/docs/Soil_map_FAOUNESCO/ new maps/IX petit.jpg

Feintrenie, L., S. Schwarze, and P. Levang. 2010. Are local people conservationists? Analysis of transition dynamics from agroforests to monoculture plantations in Indonesia. Ecology and Society 15(4): 37. http://dx.doi.org/10.5751/ES-03870-150437

Franzen, M., and M. B. Mulder. 2007. Ecological, economic and social perspectives on cocoa production worldwide. Biodiversity and Conservation 16:3835-3849. http://dx.doi.org/10.1007/ s10531-007-9183-5

Gray, L. C., and P. Morant. 2003. Reconciling indigenous knowledge with scientific assessment of soil fertility changes in southwestern Burkina Faso. Geoderma 111:425-437. http://dx. doi.org/10.1016/S0016-7061(02)00275-6

Grossman, J. 2003. Exploring farmer knowledge of soil processes in organic coffee systems of Chiapas, Mexico. Geoderma 111:267287. http://dx.doi.org/10.1016/S0016-7061(02)00268-9

Gyau, A., K. Smoot, C. Kouame, L. Diby, J. Kahia, and D. Ofori. 2014. Farmer attitudes and intentions towards trees in cocoa (Theobroma cacao L.) farms in Côte d'Ivoire. Agroforestry Systems 88:1035-1045. http://dx.doi.org/10.1007/s10457-014-9677-6

Halbrendt, J., S. A. Gray, S. Crow, T. Radovich, A. H. Kimura, and B. B. Tamang. 2014. Differences in farmer and expert beliefs and the perceived impacts of conservation agriculture. Global Environmental Change 28:50-62. http://dx.doi.org/10.1016/j. gloenvcha.2014.05.001

Hartemink, A. E. 2005. Nutrient stocks, nutrient cycling, and soil changes in cocoa ecosystems: a review. Advances in Agronomy 86:227-253. http://dx.doi.org/10.1016/S0065-2113(05)86005-5

International Fund for Agricultural Development (IFAD). 2013. Smallholders, food security and the environment. IFAD, Rome, Italy. 
Isaac, M. E., E. Dawoe, and K. Sieciechowicz. 2009. Assessing local knowledge use in agroforestry management with cognitive maps. Environmental Management 43:1321-1329. http://dx.doi. org/10.1007/s00267-008-9201-8

Janudianto, K. N., S. Isnurdiansyah, and J. Roshetko. 2012. Livelihood strategies and land use system dynamics in Southeast Sulawesi. Agroforestry and Forestry in Sulawesi Series, Working Paper 156. World Agroforestry Centre, Bogor, West Java, Indonesia.

Joshi, L., P. Shrestha, C. Moss, F. Sinclair, M. Van Noordwijk, G. Cadisch, and C. Ong. 2004. Locally derived knowledge of soil fertility and its emerging role in integrated natural resource management. Pages 17-39 in M. van Noordwijk, G. Cadisch, and C. K. Ong, editors. Below-ground interactions in tropical agroecosystems: concepts and models with multiple plant components. CABI Publishing, Walllingford, UK. http://dx.doi. org/10.1079/9780851996738.0017

Joshi, L., G. Wibawa, H. Beukema, S. Williams, and M. van Noordwijk. 2000. Technological change and biodiversity in the rubber agroecosystem of Sumatra. Tropical Agroecosystem:133155.

Lamond, G., L. Sandbrook, A. Gassner, and F. Sinclair. 2016. Local knowledge of tree attributes underpins species selection on coffee farms. Experimental Agriculture: online early. http://dx.doi. org/10.1017/S0014479716000168

Martini, E., J. M. Roshetko, and E. Paramita. 2017. Can farmerto-farmer communication boost the dissemination of agroforestry innovations? A case study from Sulawesi, Indonesia. Agroforestry Systems 91(5):811-824. http://dx.doi.org/10.1007/ $\underline{\text { s10457-016-0011-3 }}$

Martini, E., J. Tarigan, P. Purnomosidhi, A. Prahmono, M. Surgana, A. Setiawan, M. E. Megawati, B. Meldy, T. R. Syamsidar, and S. S. Janudianto. 2013. Agroforestry extension needs at the community level in AgFor project sites in South and Southeast Sulawesi, Indonesia. Agroforestry and Forestry in Sulawesi Series, Working Paper 159. World Agroforestry Centre, Bogor, West Java, Indonesia.

Mbow, C., M. van Noordwijk, E. Luedeling, H. Neufeldt, P. A. Minang, and G. Kowero. 2014. Agroforestry solutions to address food security and climate change challenges in Africa. Current Opinion in Environmental Sustainability 6:61-67. http://dx.doi. org/10.1016/j.cosust.2013.10.014

Meijer, S. S., D. Catacutan, O. C. Ajayi, G. W. Sileshi, and M. Nieuwenhuis. 2015. The role of knowledge, attitudes and perceptions in the uptake of agricultural and agroforestry innovations among smallholder farmers in sub-Saharan Africa. International Journal of Agricultural Sustainability 13:40-54. http://dx.doi.org/10.1080/14735903.2014.912493

Mulyoutami, E., J. Roshetko, E. Martini, and D. Awalina. 2015. Gender roles and knowledge in plant species selection and domestication: a case study in South and Southeast Sulawesi. International Forestry Review 17:99-111. http://dx.doi. org/10.1505/146554815816086453

Opoku-Ameyaw, K., F. Baah, E. Gyedu-Akoto, V. Anchirinah, H. Dzahini-Obiatey, A. Cudjoe, and S. Opoku. 2010. Cocoa manual - a source book for sustainable cocoa production. Cocoa Research Institute of Ghana, Tafo, Ghana.

Orwa, C., A. Mutua, R. Kindt, R. Jamnadass, and A. Simons. 2009. Agroforestry database: a tree reference and selection guide version 4.0. World Agroforestry Centre, Bogor, Nairobi, Kenya.

Pattanayak, S. K., D. E. Mercer, E. Sills, and J.-C. Yang. 2003. Taking stock of agroforestry adoption studies. Agroforestry Systems 57:173-186. http://dx.doi.org/10.1023/A:1024809108210

Pauli, N., E. Barrios, A. Conacher, and T. Oberthür. 2012. Farmer knowledge of the relationships among soil macrofauna, soil quality and tree species in a smallholder agroforestry system of western Honduras. Geoderma 189:186-198. http://dx.doi. org/10.1016/j.geoderma.2012.05.027

Pumariño, L., G. W. Sileshi, S. Gripenberg, R. Kaartinen, E. Barrios, M. N. Muchane, C. Midega, and M. Jonsson. 2015. Effects of agroforestry on pest, disease and weed control: a metaanalysis. Basic and Applied Ecology 16:573-582. http://dx.doi. org/10.1016/j.baae.2015.08.006

Rahmanulloh, A., M. Sofiyudin, and Suyanto. 2012. Profitability and isaacland-use systems in South and Southeast Sulawesi. Agroforestry and Forestry in Sulawesi Series, Working Paper 157. World Agroforestry Centre, Bogor, West Java, Indonesia.

Raymond, C. M., I. Fazey, M. S. Reed, L. C. Stringer, G. M. Robinson, and A. C. Evely. 2010. Integrating local and scientific knowledge for environmental management. Journal of Environmental Management 91:1766-1777. http://dx.doi.org/10.1016/ j.jenvman.2010.03.023

Roshetko, J. M. 2001. Agroforestry species and technologies: a compilation of the highlights and factsheets published by NFTA and FACT Net 1985-1999. Winrock International Little Rock, Arizona, USA.

Ruf, F. O. 2011. The myth of complex cocoa agroforests: the case of Ghana. Human Ecology 39:373-388. http://dx.doi. org/10.1007/s10745-011-9392-0

Sabastian, G. E., A. Yumn, J. M. Roshetko, P. Manalu, E. Martini, and A. Perdana. 2017. Adoption of silvicultural practices in smallholder timber and NTFPs production systems in Indonesia. Agroforestry Systems: online early. http://dx.doi.org/10.1007/ $\underline{\mathrm{s} 10457-017-0155-9}$

Saito, K., B. Linquist, B. Keobualapha, T. Shiraiwa, and T. Horie. 2006. Farmers' knowledge of soils in relation to cropping practices: a case study of farmers in upland rice based slash-andburn systems of northern Laos. Geoderma 136:64-74. http://dx. doi.org/10.1016/j.geoderma.2006.02.003

Sanchez, P. A., R. J. Buresh, and R. R. Leakey. 1997. Trees, soils, and food security. Philosophical Transactions of the Royal Society of London B: Biological Sciences 352:949-961. http://dx.doi. org/10.1098/rstb.1997.0074

Schroth, G., C. A. Harvey, and G. Vincent. 2004. Complex agroforests: their structure, diversity, and potential role in landscape conservation. Pages 227-260 in G. Schroth, G. A. B. da Fonseca, C. A. Harvey, C. Gason, H. L. Vasconcelos, and A.M. N. Izac, editors. Agroforestry and biodiversity conservation in tropical landscapes. Island Press, Washington, D.C.,USA. 
Schroth, G., U. Krauss, L. Gasparotto, J. D. Aguilar, and K. Vohland. 2000. Pests and diseases in agroforestry systems of the humid tropics. Agroforestry Systems 50:199-241. http://dx.doi. org/10.1023/A:1006468103914

Shiferaw, B. A., J. Okello, and R. V. Reddy. 2009. Adoption and adaptation of natural resource management innovations in smallholder agriculture: reflections on key lessons and best practices. Environment, Development and Sustainability 11:601619. http://dx.doi.org/10.1007/s10668-007-9132-1

Smith-Dumont, E., S. Bonhomme, T. Pagella, and F. Sinclair. 2017. Structured stakeholder engagement leads to development of more diverse and inclusive agroforestry options. Experimental Agriculture: online early.

Swift, M. J., A.-M. Izac, and M. van Noordwijk. 2004. Biodiversity and ecosystem services in agricultural landscapesare we asking the right questions? Agriculture, Ecosystems and Environment 104:113-134. http://dx.doi.org/https://doi.org/10.1016/ j.agee.2004.01.013

Talawar, S., and R. E. Rhoades. 1998. Scientific and local classification and management of soils. Agriculture and Human Values 15:3-14. http://dx.doi.org/10.1023/A:1007497521205

Tilman, D., K. G. Cassman, P. A. Matson, R. Naylor, and S. Polasky. 2002. Agricultural sustainability and intensive production practices. Nature 418:671-677. http://dx.doi. org/10.1038/nature01014

Tscharntke, T., Y. Clough, S. A. Bhagwat, D. Buchori, H. Faust, D. Hertel, D. Hölscher, J. Juhrbandt, M. Kessler, I. Perfecto, C. Scherber, G. Schroth, E. Veldcamp, and T. C. Wanger. 2011. Multifunctional shade-tree management in tropical agroforestry landscapes - a review. Journal of Applied Ecology 48:619-629. http://dx.doi.org/10.1111/j.1365-2664.2010.01939.x

Tscharntke, T., Y. Clough, T. C. Wanger, L. Jackson, I. Motzke, I. Perfecto, J. Vandermeer, and A. Whitbread. 2012. Global food security, biodiversity conservation and the future of agricultural intensification. Biological Conservation 151:53-59. http://dx.doi. org/10.1016/j.biocon.2012.01.068

Vanlauwe, B., K. Descheemaeker, K. Giller, J. Huising, R. Merckx, G. Nziguheba, J. Wendt, and S. Zingore. 2015. Integrated soil fertility management in sub-Saharan Africa: unravelling local adaptation. Soil 1:491-508. http://dx.doi.org/10.5194/soil-1-491-2015

van Noordwijk, M. 2017. Integrated natural resource management as pathway to poverty reduction: innovating practices, institutions and policies. Agricultural Systems: online early. http://dx.doi.org/10.1016/j.agsy.2017.10.008

van Noordwijk, M., and P. Purnomosidhi. 1995. Root architecture in relation to tree-soil-crop interactions and shoot pruning in agroforestry. Pages 161-173 in F. L. Sinclair, editor. Agroforestry: science, policy and practice. Springer, Dordrecht, The Netherlands. http://dx.doi.org/https://doi.org/10.1007/978-94-017-0681-0 8

van Straaten, P. 2006. Farming with rocks and minerals: challenges and opportunities. Anais da Academia Brasileira de Ciências 78:731-747. http://dx.doi.org/10.1590/S0001-37652006000400009
Villamor, G. B., M. van Noordwijk, U. Djanibekov, M. E. ChiongJavier, and D. Catacutan. 2014. Gender differences in land-use decisions: shaping multifunctional landscapes? Current Opinion in Environmental Sustainability 6:128-133. http://dx.doi.org/ https://doi.org/10.1016/j.cosust.2013.11.015

Vos, J. G. M., B. J. Ritchie, and J. Flood. 2003. Discovery learning about cocoa; an inspirational guide for training facilitators. World Cocoa Foundation manual, CABI Bioscience120, CAB International, Wallingford, UK.

Wartenberg, A. C., W. J. Blaser, A. Gattinger, J. M. Roshetko, M. van Noordwijk, and J. Six. 2017. Does shade tree diversity increase soil fertility in cocoa plantations? Agriculture, Ecosystems and Environment 248:190-199. http://dx.doi.org/https://doi.org/10.1016/ j.agee.2017.07.033

Watson, B. 1982. Langsat and Duku. The Archives of the Rare Fruit Council of Australia. [online] URL: http://rfcarchives.org. au/Next/Fruits/LangsatDuku/Langsat.htm

Weber, R., H. Faust, B. Schippers, S. Mamar, E. Sutarto, and W. Kreisel. 2007. Migration and ethnicity as cultural impact factors on land use change in the rainforest margins of Central Sulawesi, Indonesia. Pages 415-434 in T. Tscharntke, C. Leuschner, M. Zeller, E. Guhardja, and A. Bidin, editors. Stability of tropical rainforest margins. Springer, Heidelberg, Germany. http://dx.doi. org/10.1007/978-3-540-30290-2_20

Wyckhuys, K. A., and R. J. O’Neil. 2007. Local agro-ecological knowledge and its relationship to farmers' pest management decision making in rural Honduras. Agriculture and Human Values 24:307-321. http://dx.doi.org/10.1007/s10460-007-9068-y 
Figure A1.1 (Appendix) Mean difference in a) soil moisture and b) bulk density (BD) in the topsoil layer $(0-15 \mathrm{~cm})$ under shade-tree canopy for five shade-tree species and our control species T. cacao.

A hammer corer $(\varnothing 5.5 \mathrm{~cm})$ was used to collect 4 intact cores $(0-15 \mathrm{~cm})$ per location ("canopy" and "no canopy"). Each core was weighed individually and soil moisture content and bulk density were determined. Mean differences were calculated as the differences between mean soil parameter values measured under the canopy of individual shade trees and paired open locations. Bars represent one standard error of the mean. Asterisks indicate for which shade-tree species the difference between "canopy" and "no canopy" locations was significantly different from zero (only t-test results with p-values $<0.05$ are shown).

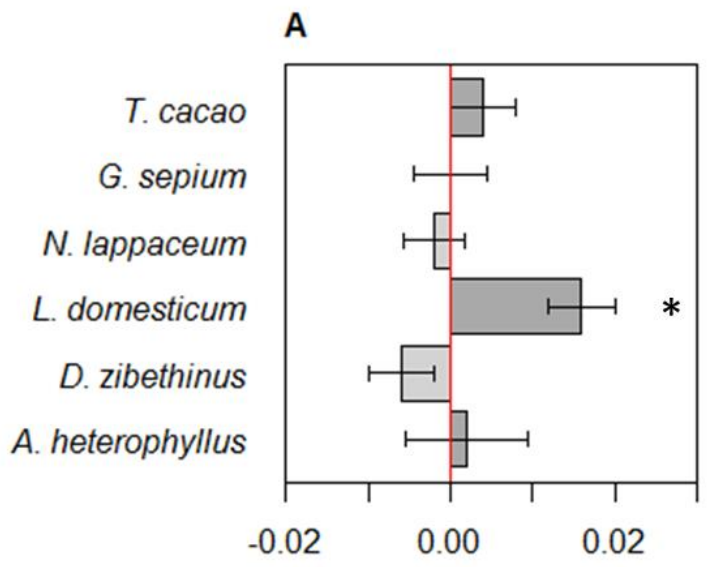

Soil Moisture change under shade-tree canopy $(\%)$

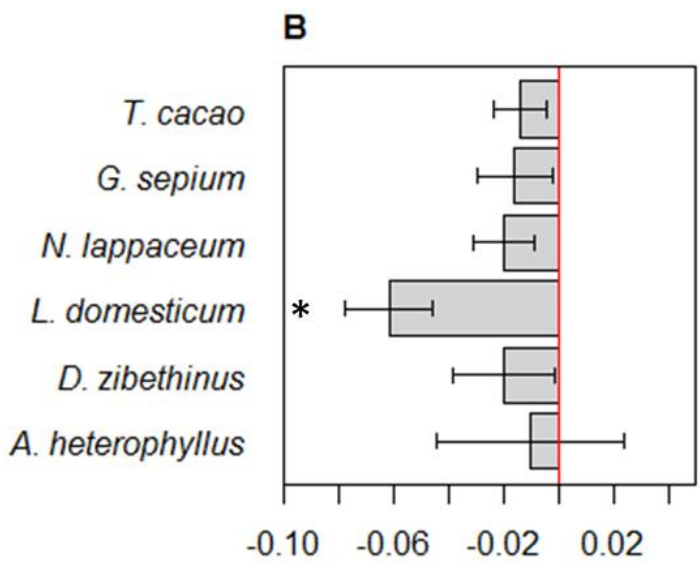

Soil BD change under shade-tree canopy $\left(\mathrm{g} \mathrm{cm}^{3}\right)$ 